\title{
ASSESSEMENT OF FLASH-FLOOD SUSCEPTIBILITY IN SMALL RIVER BASINS
}

\author{
Dragomir Andreea $^{1,2}$, Tudorache Andreea-Violeta ${ }^{1,2}$, Costache \\ Romulus ${ }^{1,3 *}$
}

Key - words: flash flood, FFPI, surface runoff, GIS

\begin{abstract}
Due to the climate changes occurred in the last decades the frequency and intensity of hydrological risk phenomena are also increasing. The flash-floods are considered the most devastating natural hazards around worldwide. The identification of areas with a high flash-flood potential and also of the valleys with a high potential for flash-flood propagation is mandatory to be included in the flashflood risk management activity. In this regard the present study proposes a GIS methodology to identify the flash-flood potential along river valleys from small catchments. The analysis carried out into a number of 5 small river basins across Romania revealed that a high percentage of river network is characterized by a high and very high flash-flood potential. The results of the present study can be successfully used in the flash-flood risk management activity and also in the activity of flash-flood forecast and warning.
\end{abstract}

\section{Introduction}

The Romanian territory has a great diversity of relief forms. The relief influences the elements of surface runoff by fragmentation degree and the size of the slopes on which the runoff is formed and indirectly, by the role it has in the vertical zone of the climatic elements that generate the leak. Delimitating surfaces with high runoff potential is very useful because the frequency of extreme meteorological events, such as torrential rainfall, has grown significantly much, causing important flash floods. Climate changes, occurred in the last decades (Bandoc and Prăvălie, 2015; Prăvălie et al., 2019; Costache and Bui, 2020; Prăvălie et al., 2017; Prăvălie and Bandoc, 2015; Costache et al., 2020b), have also a big influence on the increase of natural hazards severity. These types of studies can be very helpful in order to take the most effective measures to diminish the severity of

\footnotetext{
${ }^{1}$ Faculty of Geography, University of Bucharest, Romania

${ }^{2}$ National Institute of Hydrology and Water Management, București, Romania

${ }^{3}$ Research Institute of the University of Bucharest, Romania. *corresponding author
} 
flash-flood phenomena. In Romania, the runoff characteristics and flash-flood susceptibility were been studied by many authors in different studies (Costache, 2019a, 2014; Fontanine and Costache, 2013; Mătreață et al., 2017; Minea, 2013; Costache et al., 2014; Zaharia et al., 2012).

Flood susceptibility assessment is an important component of flood risk management activity (Costache, 2019b; Costache et al., 2020b; Costache and Bui, 2020). From a qualitative point of view, the susceptibility to flash floods can be assessed through Flash-Flood Potential Indices (Smith, 2003). The Flash-Flood Potential Index is a non-dimensional index obtained by overlapping, in the GIS environment, several flash-flood conditioning factors such as: slope, land use, lithology, soil hydrological group, slope aspect and convergence index of the river network. The FFPI provides an overview of the potential that specific areas have in development of surface runoff and further more in flash floods occurrence. The purpose of this work is to present a detailed analysis of the flash flood potential occurrence within five basins under $250 \mathrm{~km}^{2}$. In this regard the following catchments were selected for the present study: Valea Rea, Feernic, Olănești, Tecucel and Casimcea.

\section{Case studies}

Valea Rea river basin is located in the north-west part of Romania (Fig. 1a), being a right tributary of Tur river. It has a total area of $61 \mathrm{~km}^{2}$ and a river length of $14 \mathrm{~km}$, the main locality crossed being Certeze common. The average altitude in the basin is $719 \mathrm{~m}$, while the average slope is $13^{\circ}$.

Feernic river basin springs from de western slope of the volcanic plateau in the Harghita Mountains, being located in the central part of the country, in Harghita county (Fig. 1b). It is a right tributary of Târnava Mare river, with a length of $29 \mathrm{~km}$ and a basin area of $145 \mathrm{~km}^{2}$. Fernic river basin has an average altitudine of $683 \mathrm{~m}$ and an average slope of $8^{\circ}$.

Olănesti river basin is located in the central - southern part of Romania, in Vâlcea county (Fig. 1c). Olănești river is one of the important tributaries of the Olt river on the right side. The total basin area is $226 \mathrm{~km}^{2}$ and the river length is $33 \mathrm{~km}$. The study area is identified as one of the areas with potentially significant flash flood risk due to the physical and geographical features of the basin. The average altitude in the basin is $764 \mathrm{~m}$, while the average slope is $16^{\circ}$.

Tecucel river basin is located in the eastern part of Romania (Fig. 1d), being the last tributary on the right side of the Bârlad river, before its confluence with Siret river. It has a surface area of $110 \mathrm{~km}^{2}$ and a total river length of $26 \mathrm{~km}$. 


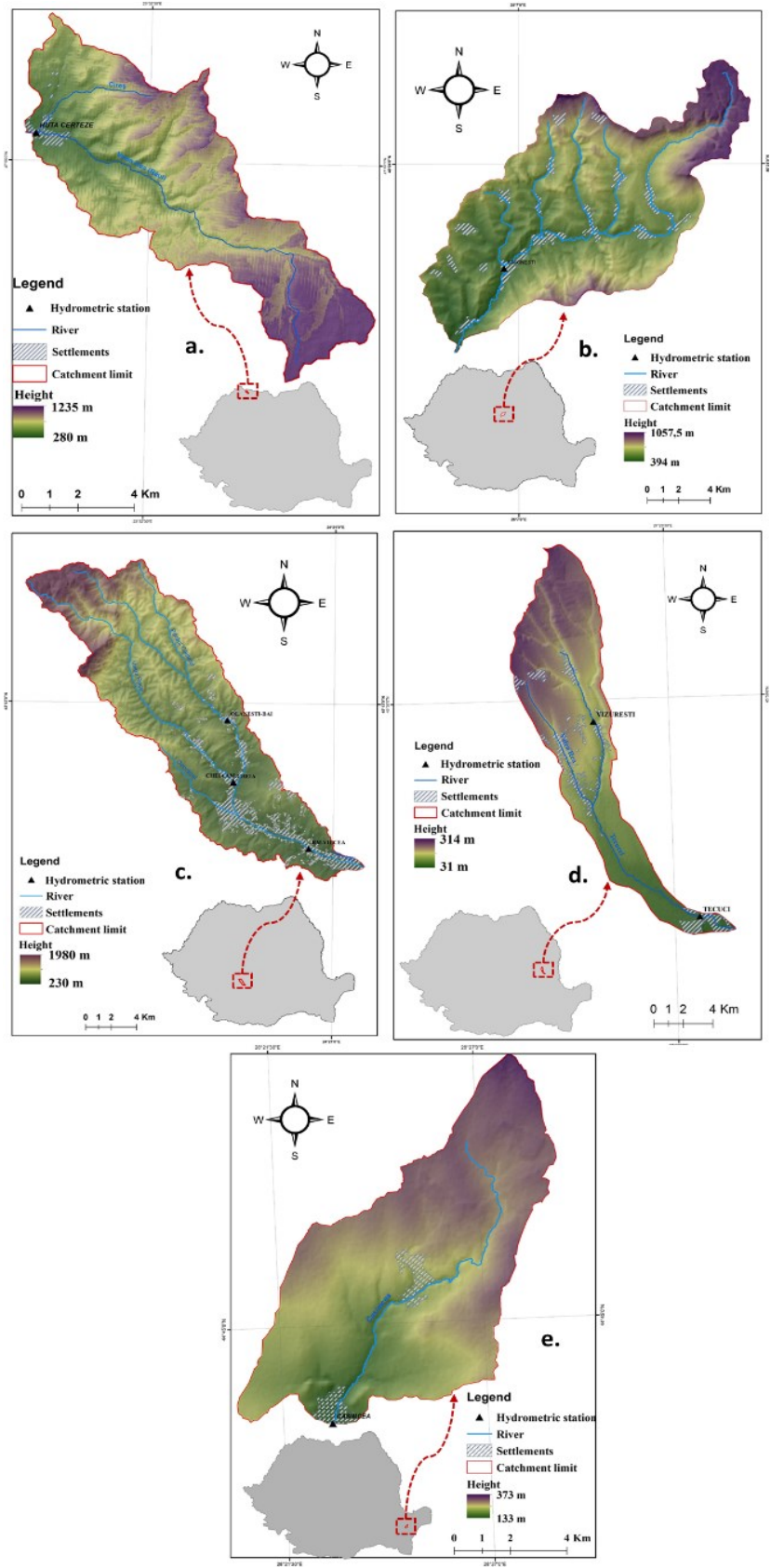

Fig. 1. Case study catchments (a. Valea Rea, b. Feernic, c. Olănești, d. Tecucel, e. Casimcea) 
Tecucel river crosses Tecuci town on a length of $8.2 \mathrm{~km}$. Tecucel river basin has an average altitudine of $179 \mathrm{~m}$ and an average slope river is $3^{\circ}$.

Casimcea river is the most important watercourse of Dobrogea region. It is located in the south-east part of the country, crossing Tulcea and Constanța counties. For this study, we chose to analise the basin area corresponding to Casimcea hydrometric station. It is located in the upper part of the basin (Fig. 1d), the surface of the station being $78 \mathrm{~km}^{2}$ and the length of the Casimcea river up to the station with the same name, is $16 \mathrm{~km}$.

\section{Methodology}

In order to determine flash-flood susceptibility across the selected catchments, several geographical factors were included into a GIS workflow which involve the use of Map Algebra and Flow Accumulation procedure. Thus, the computation of FFPI was possible by using the following flash-flood predictors: slope, land use, lithology, hydrographic convergence index and aspect.

According to the literature (Bui et al., 2020; Costache, 2019c; Hong et al., 2018; Khosravi et al., 2019), the slope of the relief was considered to be the most important factor for rapid surface runoff. Thus, the high slopes received highest score, while the lower slopes received lowest score. A similar weight to the slope, also received the land use. For land use, forests were considered the most restrictive areas for rapid surface runoff, while the built areas and grasslands received the highest score due to the low values of the Manning roughness coefficients (Costache et al., 2020a, 2019b, 2015; Costache and Bui, 2019; Costache and Zaharia, 2017; Wang et al., 2019). From soil perspective, hydrologic $\mathrm{D}$ group is the most favorable for rapid surface runoff because it has the lowest potential for water infiltration (Costache et al., 2020c, 2019a). The hard rocks have the lowest permeability, thus favoring the intense surface runoff and therefore formation of flash floods. The high values of the hydrographic convergence allow the generation of a torrential flow of water in a river basin. A high favorability for surface runoff occurs during the summer on the slopes exposed to solar radiation where the upward thermal convection often gives rise to Cumulonimbus clouds that generate torrential rains. During the spring the southern slopes are also more exposed to the formation of flash floods due to the melting, which is more intense.

All the aforementioned flash-flood predictors were reclassified in GIS environment by assigning a specific score to each class/category according to its influence on surface runoff manifestation. Further, these factors were summed up in Map Algebra in order to derive the FFPI values. The FFPI values highlights the potential of the slopes to generate rapid surface runoff. Taken individually, this phenomenon is responsible for surface erosion. Damage associate with rapid surface runoff is caused by the flash floods that forms on the valleys of the rivers 
where the initial runoff formed on the slopes is concentrated. For this reason, we proceed to compute the average values of FFPI corresponding to each point/pixel of the river network. It should be mentioned that the FFPI values on river network will be equal to the mean value of the upslope catchment. Thus, each point that forms the hydrographic network will retrieve the average FFPI value of all upstream cells that flow into it. The achievement of the average FFPI values was facilitated by Flow Accumulation procedure.

For faster execution of the workflow in the GIS environment related to the operation described above, the Model Builder application was used (Fig. 6).

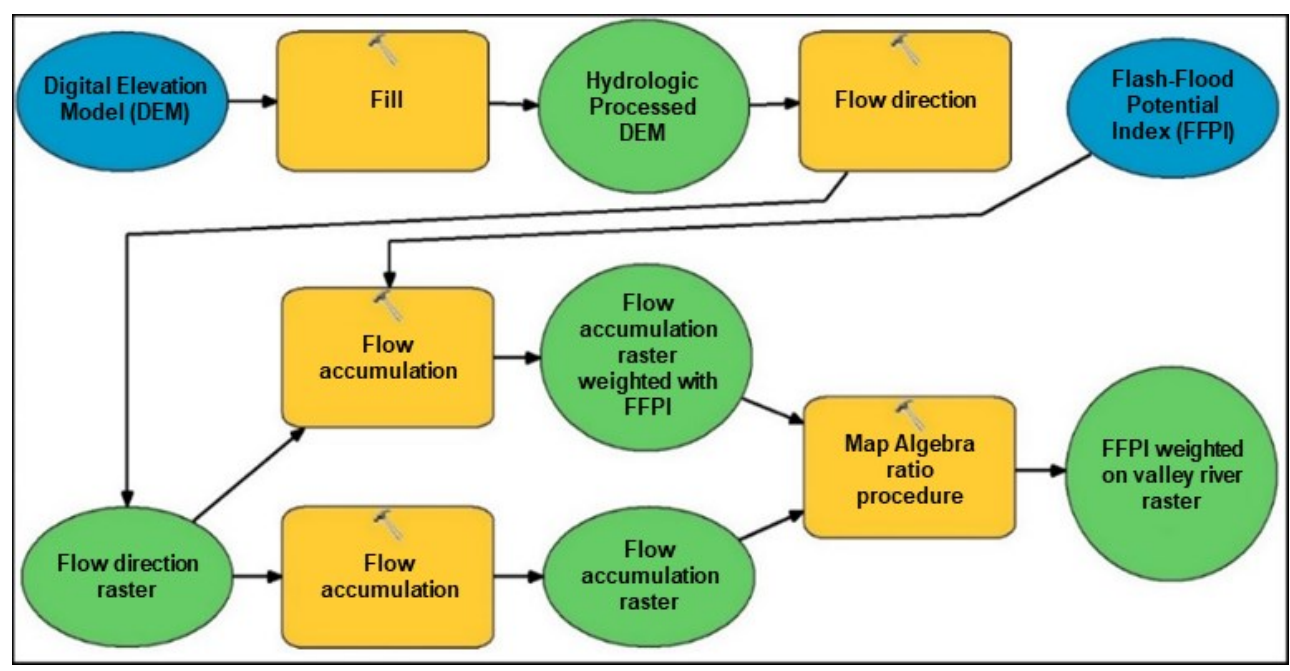

Fig. 2. Scheme of GIS workflow developed to calculate the FFPI values averaged on river network

\section{Results and discussions}

Thus, the FFPI index was applied to the 5 basins chosen for the analysis in order to determine the potential flash flood occurrence: Valea Rea river basin (Fig 3), Fernic river basin (Fig. 4), Olănești river basin (Fig. 5), Tecucel river basin (Fig. 6), Casimcea river basin (Fig. 7). 


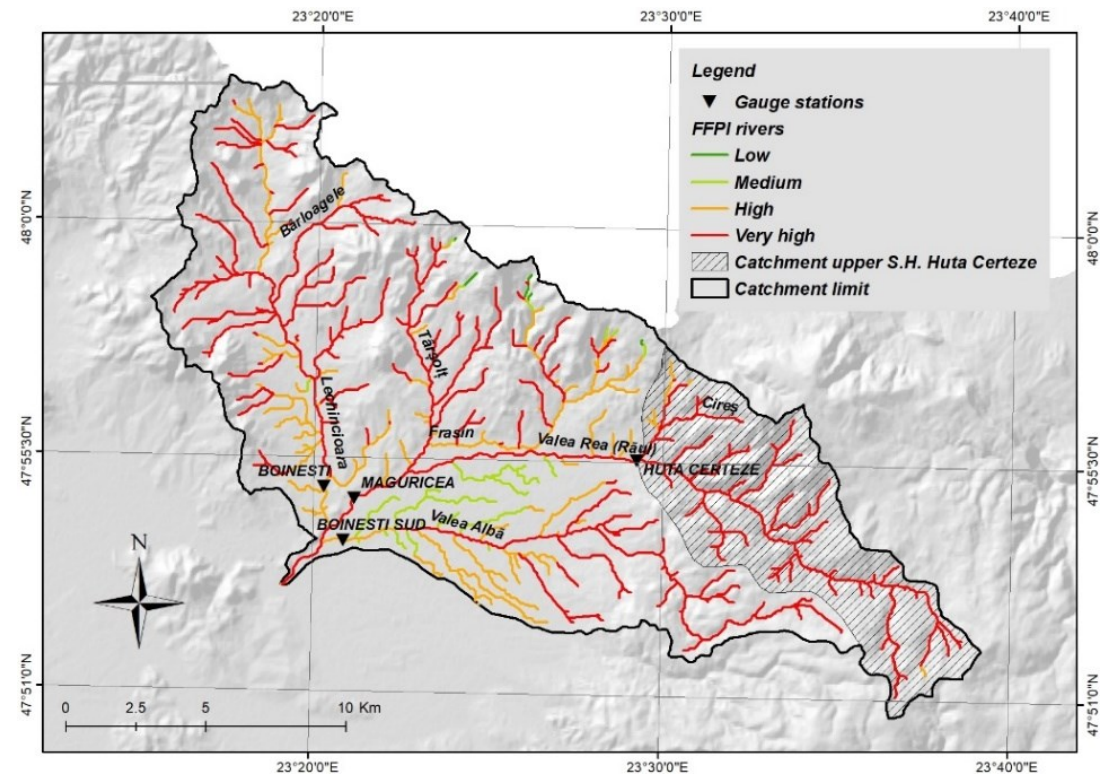

Fig. 3 The FFPI values distribution in Valea Rea river basin

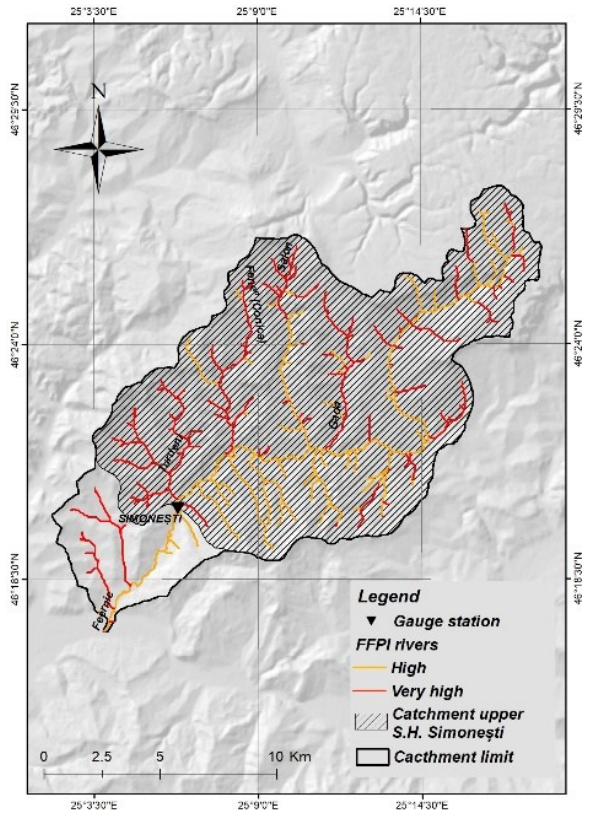

Fig. 4 The FFPI values within Fernic river basin

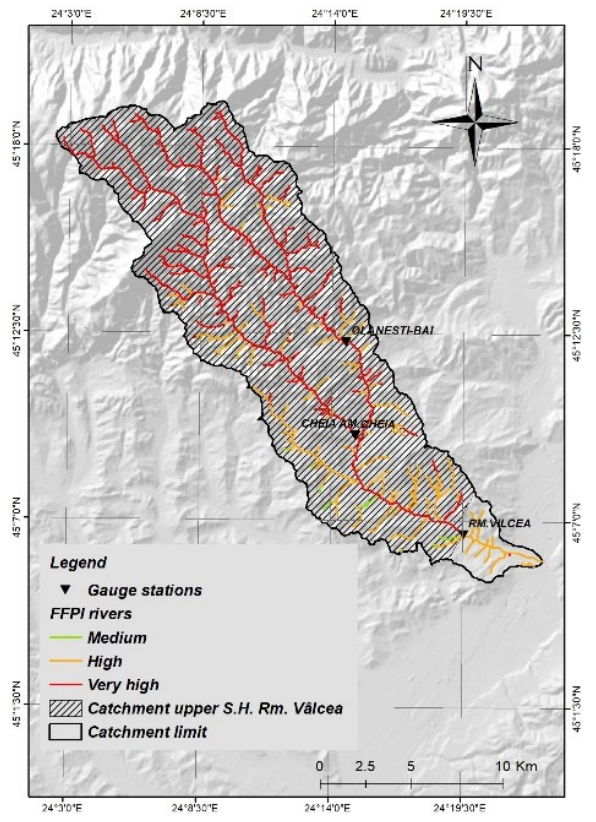

Fig. 5 The FFPI values within Olănești river basin 


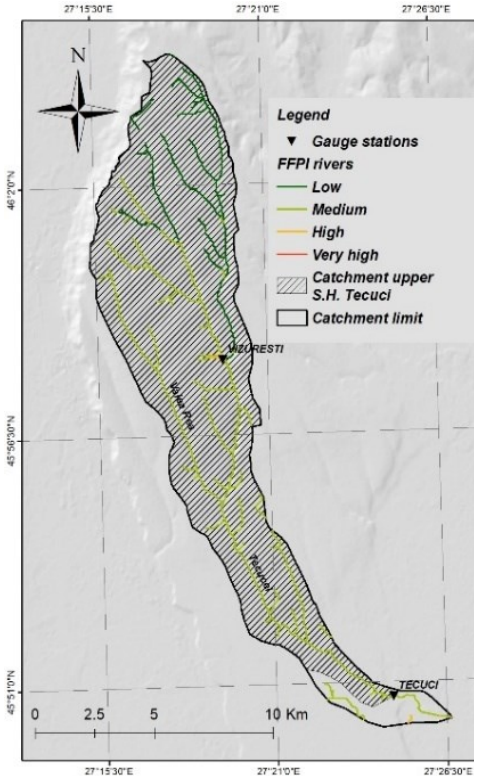

Fig. 6. FFPI values within Tecucel river basin

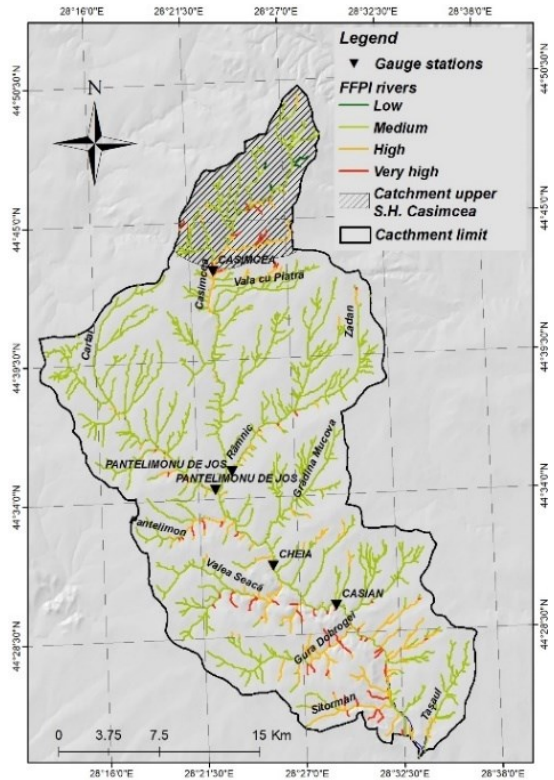

Fig. 7. FFPI values within Casimcea river basin

In terms of Valea Rea river basin, the very high values of flash-flood potential characterize approximately $67 \%$ of the total river length, while the other three classes accounts $33 \%$ of the river network (Fig. 8).

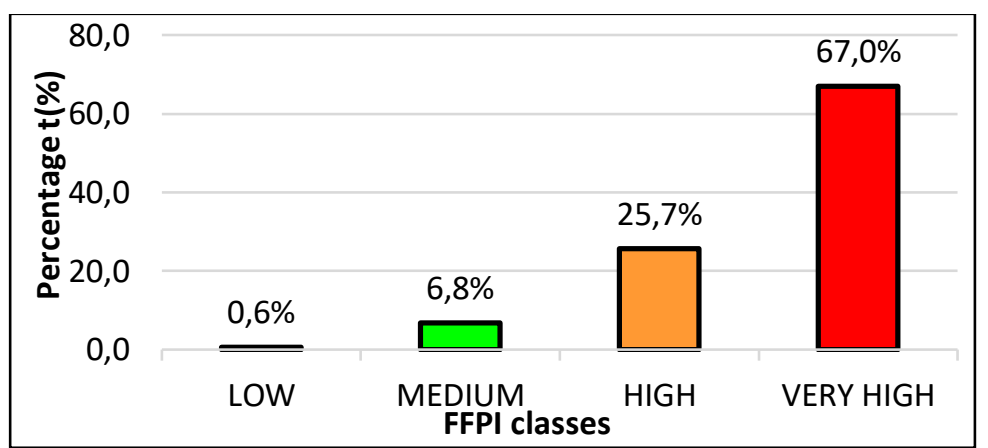

Fig. 8 Weights of FFPI classes within Valea Rea catchment

Feernic river basin is notable for the the presence of valleys with high and very high potential for development of flash floods. The two hazard classes share approximately equal percentages from the valleys delimited in the GIS environment (Fig. 9). The values of the potential development of flash floods that 
characterize the valleys in the Feernic basin area, make it an area exposed to the flash floods and fully justify the choice of this basin for case study in the present paper.

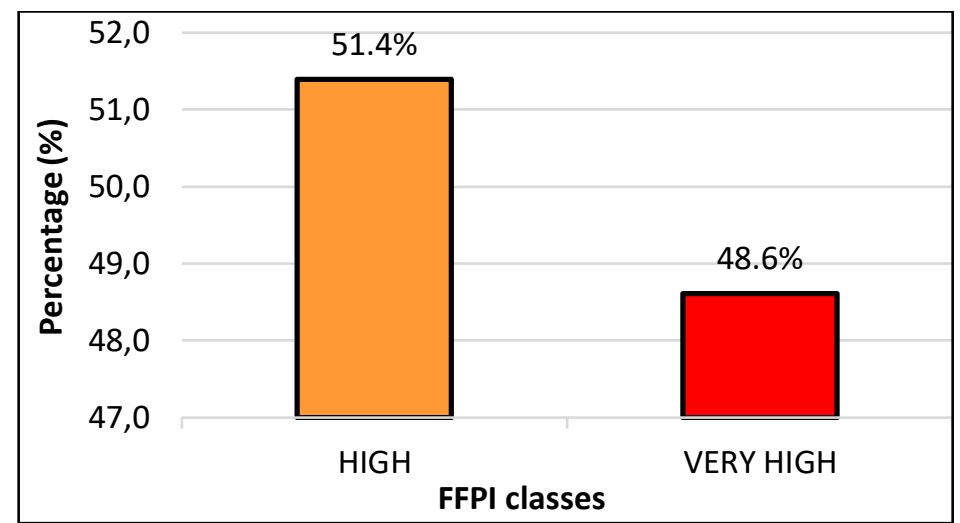

Fig. 9 Weights of FFPI classes within Feernic catchment

The third basin taken into account for a detailed analysis is Olanesti river basin, in Valcea county. Râmnicu Valcea is the closing point of the considered basin section. Almost $100 \%$ of the defined hydrographic network is characterized by the presence of valleys with a high and very flash-flood potential (Fig. 10).

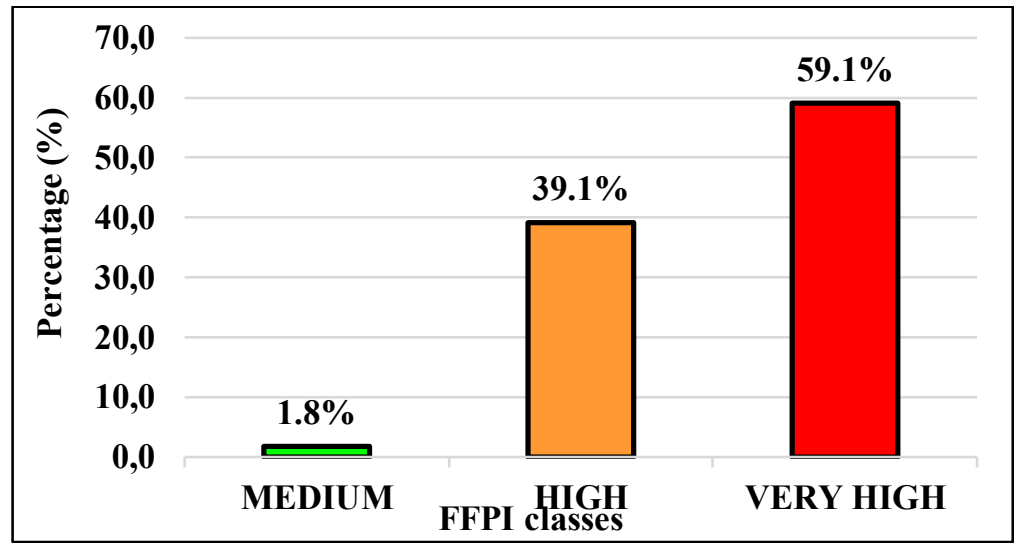

Fig. 10 Weights of FFPI classes within Olănești catchment

The fourth basin considered is Tecucel River. The results of the workflow developed in GIS environment showed that the valleys in the Tecucel river basin have a medium $(68 \%)$ and low $(30.1 \%)$ torrential potential (fig. 16).The 
consideration of this basin for detailed analysis is justified by the fact that although in general the valleys do not present a high torrential potential here severe events have been recorded in the past, significant being on 06/09/2007.

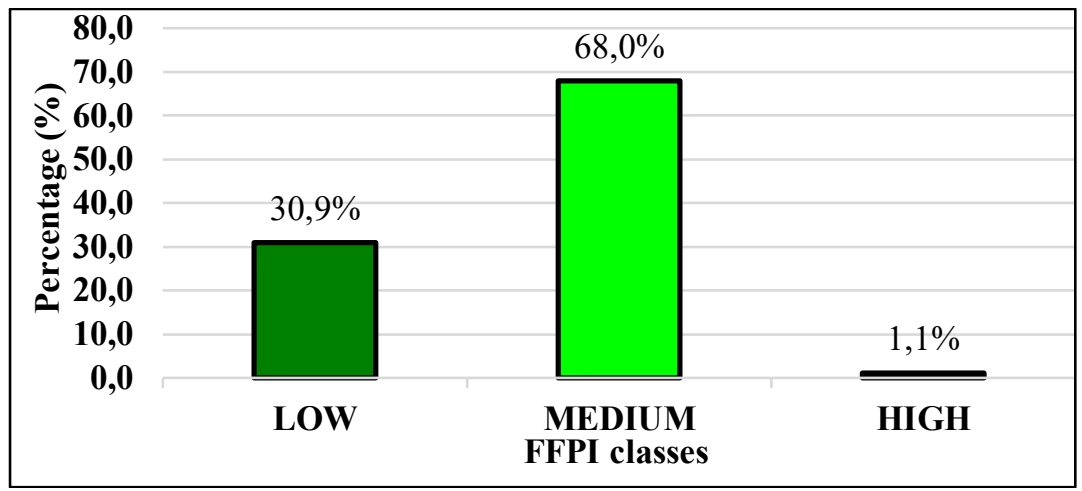

Fig. 11 Weights of FFPI classes within Tecucel catchment

Dobrogea is the fifth region of the country represented by a river basin considered in the present study. For analysis, it was taken into account the basin section which corresponds to Casimcea hydrometric station, from Casimcea river basin. As in the case of Tecucel river basin, the majority of the valleys from Casimcea catchment are characterized by a medium potential for flash floods occurence $(81.2 \%)$, while $14.5 \%$ of them have a high potential and only $3.9 \%$ a very high potential (fig. 17).

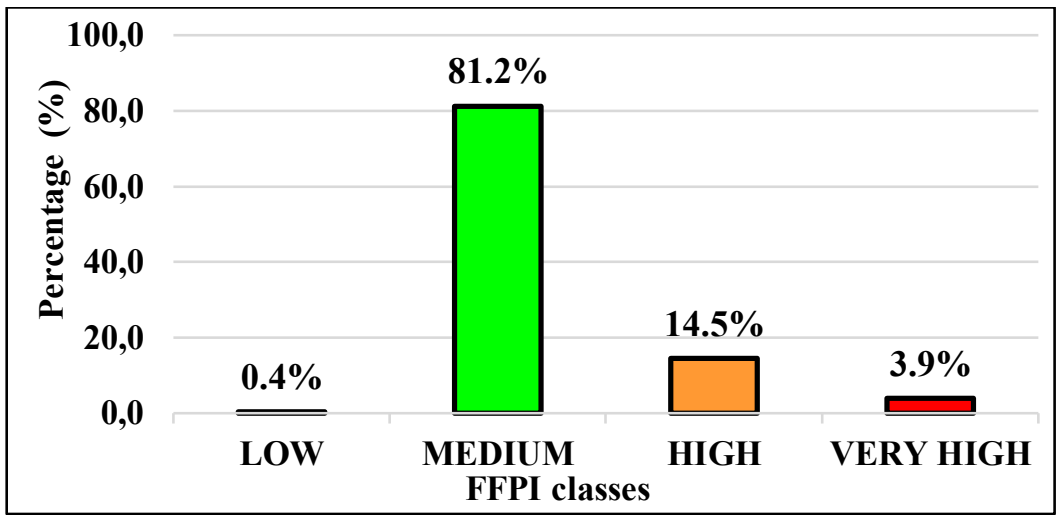

Fig. 12 Weights of FFPI classes within Casimcea catchment 


\section{Conclusions}

The present research aims to assess the torrentiality degree of river network within a number of five small catchments inside Romanian territory. The entire analysis was supported by GIS techniques. The catchment selected for case studies were: Valea Rea, Feernic, Olănești, Tecucel and Casimcea. All these river basins have a surface smaller than $250 \mathrm{~km}^{2}$. By using the GIS techniques, the valleys of the rivers most exposed to the phenomena associated with the torrentiality were identified. According to the results achieved in the present paper, the river valleys from Olănești and Valea Rea catchments are the most susceptible to flash-floods. It should be mentioned that the high and very high FFPI values are present on the valleys that have an upper basin characterized by high slope angles, a low afforestation degree, a high percentage of soil from hydrological group D and also a high degree of hydrographic convergence. Also, it can be observed that the FFPI values are higher in the areas with a high altitude. These variables could, therefore, explain the differences between the flash-flood susceptibility of the valleys from the 5 river basins. Thus, it is normal that some catchments like Olăneşti and Valea Rea, which span on mountain and hilly areas with high slopes, to have a higher percentage of high and very high flash-flood potential, than catchments like Tecucel and Casimcea which are located in areas with a lower slope angle and altitude. Establishing the average values of the FFPI on each cell that forms the cadastral and non-cadastral hydrographic network is a real help in issuing forecasts and warnings for flash floods. When analysing precipitation data and evaluating the potential of flash floods existing at the level of a river, the decision to issue or not an immediate phenomena warning can be taken very quickly.

\section{References}

1. Bandoc, G., Prăvălie, R. (2015), Climatic water balance dynamics over the last five decades in Romania's most arid region, Dobrogea, J. Geogr. Sci. 25, 1307-1327. https://doi.org/10.1007/s11442-015-1236-1

2. Bui, D.T., Hoang, N.-D., Martínez-Álvarez, F., Ngo, P.-T.T., Hoa, P.V., Pham, T.D., Samui, P., Costache, R. (2020), A novel deep learning neural network approach for predicting flash flood susceptibility: A case study at a high frequency tropical storm $\begin{array}{lllll}\text { area } & \text { Sci. Total } & \text { Environ. } & \text { 701, } & 134413 .\end{array}$ https://doi.org/10.1016/j.scitotenv.2019.134413

3. Costache, R. (2014) Using GIS techniques for assessing lag time and concentration time in small river basins. Case study: Pecineaga river basin, Romania. Geo. Tec. 9, 3138.

4. Costache, R., Fontanine, F., Corodescu E. (2014), Assessment of surface runoff depth changes in Sărăţel River basin, Romania using GIS techniques, Open Geosci. 6, 363372. https://doi.org/10.2478/s13533-012-0181-0 
5. Costache, R. (2019a), Flash-flood Potential Index mapping using weights of evidence, decision Trees models and their novel hybrid integration, Stoch. Environ. Res. Risk Assess. 33, 1375-1402. https://doi.org/10.1007/s00477-019-01689-9

6. Costache, R. (2019b), Flood Susceptibility Assessment by Using Bivariate Statistics and Machine Learning Models-A Useful Tool for Flood Risk Management, Water Resour. Manag. 33, 3239-3256. https://doi.org/10.1007/s11269-019-02301-z

7. Costache, R. (2019c), Flash-Flood Potential assessment in the upper and middle sector of Prahova river catchment (Romania). A comparative approach between four hybrid models, Sci. Total Environ. https://doi.org/10.1016/j.scitotenv.2018.12.397

8. Costache, R., Bui, D.T. (2019), Spatial prediction of flood potential using new ensembles of bivariate statistics and artificial intelligence: A case study at the Putna river catchment of Romania, Sci. Total Environ. 691, 1098-1118. https://doi.org/10.1016/j.scitotenv.2019.07.197

9. Costache, R., Bui, D.T. (2020), Identification of areas prone to flash-flood phenomena using multiple-criteria decision-making, bivariate statistics, machine learning and their ensembles, Sci. Total Environ. 712, 136492. https://doi.org/10.1016/j.scitotenv.2019.136492

10. Costache, R., Hong, H., Pham, Q.B. (2019a), Comparative assessment of the flashflood potential within small mountain catchments using bivariate statistics and their novel hybrid integration with machine learning models, Sci. Total Environ. 134514. https://doi.org/10.1016/j.scitotenv.2019.134514

11. Costache, R., Hong, H., Wang, Y. (2019b), Identification of torrential valleys using GIS and a novel hybrid integration of artificial intelligence, machine learning and bivariate statistics, Catena 183, 104179. https://doi.org/10.1016/j.catena.2019.104179

12. Costache, R., Pham, Q.B., Avand, M., Linh, N.T.T., Vojtek, M., Vojteková, J., Lee, S., Khoi, D.N., Nhi, P.T.T., Dung, T.D. (2020a), Novel hybrid models between bivariate statistics, artificial neural networks and boosting algorithms for flood susceptibility $\begin{array}{lllll}\text { assessment, } & \text { J. } & \text { Environ. } & \text { Manage. } & 265,\end{array}$ https://doi.org/10.1016/j.jenvman.2020.110485

13. Costache, R., Pham, Q.B., Sharifi, E., Linh, N.T.T., Abba, S., Vojtek, M., Vojteková, J., Nhi, P.T.T., Khoi, D.N. (2020b), Flash-Flood Susceptibility Assessment Using Multi-Criteria Decision Making and Machine Learning Supported by Remote Sensing and GIS Techniques, Remote Sens. 12, 106. https://doi.org/10.3390/rs12010106

14. Costache, R., Popa, M.C., Bui, D.T., Diaconu, D.C., Ciubotaru, N., Minea, G., Pham, Q.B. (2020c), Spatial predicting of flood potential areas using novel hybridizations of fuzzy decision-making, bivariate statistics, and machine learning, J. Hydrol. 124808. https://doi.org/10.1016/j.jhydrol.2020.124808

15. Costache, R., Pravalie, R., Mitof, I., Popescu, C. (2015), Flood vulnerability assessment in the low sector of Saratel Catchment. Case study: Joseni Village, Carpathian J. Earth Environ. Sci. 10, 161-169.

16. Costache, R., Zaharia, L. (2017), Flash-flood potential assessment and mapping by integrating the weights-of-evidence and frequency ratio statistical methods in GIS 
environment - case study: Bâsca Chiojdului River catchment (Romania), J. Earth Syst. Sci. 126, 59. https://doi.org/10.1007/s12040-017-0828-9

17. Fontanine, I., Costache, R. (2013), Using GIS techniques for surface runoff potential analysis in the Subcarpathian area between Buzãu and Slãnic rivers, in Romania, Cinq Cont. 3, 47-57.

18. Hong, H., Tsangaratos, P., Ilia, I., Liu, J., Zhu, A.-X., Chen, W. (2018), Application of fuzzy weight of evidence and data mining techniques in construction of flood susceptibility map of Poyang County, China. Sci. Total Environ. 625, 575-588. https://doi.org/10.1016/j.scitotenv.2017.12.256

19. Khosravi, K., Shahabi, H., Pham, B.T., Adamowski, J., Shirzadi, A., Pradhan, B., Dou, J., Ly, H.-B., Gróf, G., Ho, H.L. (2019), A comparative assessment of flood susceptibility modeling using Multi-Criteria Decision-Making Analysis and Machine $\begin{array}{llll}\text { Learning Methods, H. 311-323. } & \end{array}$ https://doi.org/10.1016/j.jhydrol.2019.03.073

20. Mătreață, M., Mătreață, S., Costache, R.-D., Mihalcea, A., Manolache, A.V. (2017), Assessment of Flash Flood Hazard Maps Using Different Threshold Values and Indices Methods, Artic. Submiss. 49. 16), pp. 49-54 (6) http://dx.doi.org/10.5775/fg.2016.059.s

21. Minea, G. (2013), Assessment of the flash flood potential of Bâsca River Catchment (Romania) based on physiographic factors, Open Geosci. 5, 344-353. https://doi.org/10.2478/s13533-012-0137-4

22. Prăvălie, R., Bandoc, G. (2015), Aridity variability in the last five decades in the Dobrogea region, Romania, Arid Land Res. Manag. 29, 265-287. https://doi.org/10.1080/15324982.2014.977459

23. Prăvălie, R., Bandoc, G., Patriche, C., Sternberg, T. (2019), Recent changes in global drylands: Evidences from two major aridity databases, Catena 178, 209-231. https://doi.org/10.1016/j.catena.2019.03.016

24. Prăvălie, R., Bandoc, G., Patriche, C., Tomescu, M. (2017), Spatio-temporal trends of mean air temperature during 1961-2009 and impacts on crop (maize) yields in the most important agricultural region of Romania. Stoch. Environ, Res. Risk Assess. 31, 1923-1939. https://doi.org/10.1007/s00477-016-1278-7

25. Smith, G. (2003), Flash flood potential: Determining the hydrologic response of FFMP basins to heavy rain by analyzing their physiographic characteristics. White Pap. Available NWS Colo. Basin River Forecast Cent, Web Site http//www. Cbrfc Noaa Govpapersffpwpap Pdf.

26. Wang, Y., Hong, H., Chen, W., Li, S., Panahi, M., Khosravi, K., Shirzadi, A., Shahabi, H., Panahi, S., Costache, R. (2019), Flood susceptibility mapping in Dingnan County (China) using adaptive neuro-fuzzy inference system with biogeography based optimization and imperialistic competitive algorithm, J. Env. Manage. 247, 712-729. https://doi.org/10.1016/j.jenvman.2019.06.102

27. Zaharia, L., Minea, G., Ioana-Toroimac, G., Barbu, R., Sârbu, I. (2012), Estimation of the areas with accelerated surface runoff in the upper Prahova watershed (Romanian Carpathians), Balwois, Repub. Maced. 